DOI: https://doi.org/10.47405/mjssh.v6i9.1042

\begin{tabular}{|c|c|}
\hline 4 & Malaysian Journal of Social Sciences and Humanities (MJSSH) \\
\hline $\begin{array}{l}\text { Malaysian Juoural of } \\
\text { Social ccciecces and }\end{array}$ & Volume 6, Issue 9, September 2021 \\
\hline (MJ-sSH) & e-ISSN : 2504-8562 \\
\hline & $\begin{array}{l}\text { Journal home page: } \\
\text { www.msocialsciences.com }\end{array}$ \\
\hline
\end{tabular}

\title{
Pencegahan Jenayah Pecah Rumah Bagi Menjamin Keselamatan Masyarakat: Suatu Pemerhatian Awal
}

\author{
Nur Farhana Abd Malek ${ }^{1}$, Hezzrin Mohd Pauzi' ${ }^{1}$ Normah Awang Noh ${ }^{1}$ \\ ${ }^{1}$ Fakulti Sains Sosial Gunaan, Universiti Sultan Zainal Abidin (UNISZA) \\ Correspondence: Nur Farhana Abd Malek (farhanamalek89@yahoo.com)
}

\begin{abstract}
Abstrak
Permasalahan jenayah pecah rumah merupakan suatu permasalahan sosial yang memberikan kesan kepada keselamatan masyarakat. Jenayah pecah rumah ini merupakan suatu jenayah harta benda yang sering terjadi dan jenayah ini kerap dilaporkan berbanding jenayah kekerasan di Malaysia. Amalan pencegahan jenayah perlu dilaksanakan dalam mengawal permasalahan jenayah pecah rumah supaya dapat menjamin keselamatan masyarakat Malaysia. Artikel ini bertujuan untuk membincangkan mengenai langkah-langkah pencegahan jenayah pecah rumah bagi menjamin keselamatan masyarakat. Kaedah kajian yang digunakan adalah berdasarkan kepada penelitian terhadap kajian-kajian lepas. Oleh itu, penelitian kajian lepas bagi langkah-langkah pencegahan jenayah pecah rumah akan dibincangkan. Langkah pencegahan seperti pemantauan pihak berkuasa PDRM, pengawasan komuniti, meningkatkan ciri-ciri keselamatan dan pemilihan komuniti berpagar merupakan amalan pencegahan yang dapat mengurangkan risiko jenayah pecah rumah berlaku. Kesimpulannya, langkah-langkah pencegahan berkenaan haruslah dititikberatkan supaya dapat mencegah daripada berlakunya jenayah pecah rumah. Artikel ini juga diharapkan dapat membantu pihak bertanggungjawab dalam melaksanakan pencegahan jenayah pecah rumah bagi menjamin keselamatan dan kesejahteraan masyarakat.
\end{abstract}

Kata kunci: jenayah pecah rumah, pencegahan jenayah, keselamatan masyarakat

\section{Housebreaking Crime Prevention to Ensure Community Safety: A Preliminary Observation}

\begin{abstract}
The problem of burglary is a social problem that affects the safety of society. This burglary is a common property crime and this crime is often reported compared to violent crimes in Malaysia. Crime prevention practices need to be implemented in controlling the problem of burglary in order to ensure the safety of the Malaysian community. This article aims to discuss about housebreaking crime prevention measures to ensure community safety. The research method used is based on the review of previous studies. Therefore, a review of past studies for burglary crime prevention measures will be discussed. Preventive measures such as monitoring by PDRM authorities, community surveillance, improving security features and selection of gated communities are preventive practices that can reduce the risk of burglary. In conclusion, such preventive measures should be emphasized in order to prevent the occurrence of burglary. This article is also expected to help those responsible in implementing the prevention of burglary to ensure the safety and well-being of the community.
\end{abstract}

Keywords: burglary, crime prevention, community safety 


\section{Pengenalan}

Perlakuan jenayah seperti jenayah pecah rumah bukanlah suatu isu yang baru malah masalah jenayah ini sering kali dibangkitkan oleh pelbagai ahli akademik dan media massa. Peningkatan masalah jenayah ini adalah seiring dengan kepesatan suatu pembangunan sesebuah bandar itu (Ahmad Tarmizi et al., 2017). Ini disokong oleh Nor-Ina et al. (2015) yang turut berpendapat bahawa kepesatan suatu perbandaran serta pembangunan di Malaysia akan membawa kepada peningkatan masalah perlakuan jenayah yang cenderung membawa kepada kebimbangan dan mewujudkan rasa tidak selamat dalam kalangan masyarakat. Peningkatan masalah jenayah merupakan salah satu daripada permasalahan sosial yang akan memberikan kebimbangan kepada seluruh dunia (Norita et al., 2020). Tambahan pula, masalah jenayah memberikan kesan yang lebih besar daripada apa yang masyarakat fikirkan (Farhan, 2020).

Menurut Norita et al. (2019), permasalahan jenayah harta benda merupakan jenayah indeks yang kerap dilaporkan berlaku di dalam Malaysia berbanding permasalahan jenayah kekerasan. Masalah jenayah ini bukan sahaja membawa masalah dari segi kehilangan harta benda malah turut memberikan kesan terhadap psikologi masyarakat di sesebuah negara. Sementara itu, menurut Rozaimi dan Narimah (2017) suatu perlakuan jenayah yang berlaku dapat menimbulkan permasalahan dari segi aspek keselamatan juga. Ini kerana aspek keselamatan telah menjadi ancaman kepada masyarakat mahupun individu di kawasan bandar akibat daripada perkembangan proses pembandaran yang berlaku.

Masalah jenayah ini bukan lagi suatu dimensi baru dalam permasalahan jenayah tetapi telah berkembang mengikut trend (Za'im et al., 2017). Kadar jenayah yang berlaku di bandar di dunia telah menunjukkan suatu trend yang meningkat termasuk di Malaysia (Faizah et al., 2015). Peningkatan ini bukan sahaja membimbangkan malah ia sebagai penunjuk bahawa ketidakberkesanan amalan pencegahan yang telah dilakukan dalam membendung jenayah malah susun atur atau reka bentuk fizikal di sesebuah bandar itu tidak membantu dalam mewujudkan persekitaran yang selamat kepada masyarakat. Oleh yang demikian, langkah-langkah yang lebih proaktif dan komprehensif bagi mencegah atau mengurangkan daripada berlakunya masalah jenayah ini perlu dilakukan (Za'im et al., 2017).

Di Malaysia, beberapa langkah pencegahan telah dilaksanakan bagi tujuan mengurangkan masalah jenayah iaitu dari segi penggubalan undang-undang, dasar, polisi, penubuhan institusi dan sebagainya. Penggubalan undang-undang jenayah iaitu Kanun Keseksaan dan Kanun Tatacara Jenayah telah digubal di Parlimen bagi sistem keadilan jenayah di Malaysia demi mengawal masalah jenayah (Nurhafilah, 2015; Mohd Zul Fahmi, 2019). Peruntukkan undang-undang yang telah ditetapkan di bawah Kanun Keseksaan telah sedia ada menggariskan pelbagai hukuman dan perbuatan bagi kesalahan jenayah kekerasan dan khususnya bagi jenayah harta benda untuk mengenakan tindakan kepada mereka yang melakukan kesalahan berkait jenayah ini (Za'im et al., 2017). Sementara itu, dalam usaha mencegah masalah jenayah ini pihak kerajaan Malaysia telah melaksanakan pelbagai dasar dan pendekatan bagi menangani perlakuan jenayah ini dengan penubuhan Yayasan Pencegahan Jenayah Malaysia (YPJM) atau Malaysia Crime Prevention Foundation (MCPF) pada tahun 1993 iaitu semasa di bawah pemerintahan mantan Perdana Menteri ke-4 iaitu Tun Dr Mahathir Mohamad (NorIna et al., 2015).

Yayasan Pencegahan Jenayah Malaysia (YPJM) adalah bagi tujuan meningkatkan kesedaran dan penyertaan masyarakat dalam usaha mencegah jenayah serta langkah-langkah yang berkesan bagi pencegahan masalah jenayah yang berlaku (Mohd Zul Fahmi, 2019). Pihak kerajaan Malaysia juga telah melaksanakan langkah pencegahan lain iaitu menerusi Program Transformasi Kerajaan (GTP) yang diumumkan oleh mantan Perdana Menteri ke-6 iaitu Y.A.B Dato' Sri Mohd Najib bin Tun Haji Razak pada 28 Januari 2010. Terdapat enam Bidang Keberhasilan Utama Negara (NKRA) yang telah menjadi tonggak kepada Program Transformasi Kerajaan (GTP) ini iaitu bagi mengurangkan jenayah, membanteras rasuah, mempertingkatkan pencapaian pelajar, meningkatkan taraf hidup isi rumah 
berpendapatan rendah, mempertingkatkan infrastruktur asas luar bandar serta pengangkutan awam bandar (Kementerian Dalam Negeri, 2021). Menerusi program ini juga satu Jabatan Pencegahan Jenayah Dan Keselamatan Komuniti (JPJKK) telah ditubuhkan pada 9 Jun 2014 oleh Ketua Polis Negara bagi tujuan merangka strategi, melaksanakan pelbagai inisiatif bagi tujuan mengurangkan masalah jenayah dan meningkatkan persepsi keselamatan (Polis Diraja Malaysia, 2016b).

Permasalahan jenayah merupakan suatu perkara utama yang merisaukan masyarakat dan masih belum ada langkah yang sempurna dalam membanteras masalah jenayah ini secara keseluruhannya (Fauziah, 2016). Oleh itu, artikel ini akan membincangkan berkait langkah-langkah pencegahan yang boleh dilakukan bagi mencegah permasalahan jenayah khususnya jenayah pecah rumah menerusi penelitian beberapa kajian lepas bagi menjamin keselamatan dan kesejahteraan masyarakat di Malaysia. Hal ini kerana, masalah jenayah yang meningkat telah mengancam keselamatan serta kesejahteraan masyarakat (Saravanan, 2010). Tambahan pula, perbuatan jenayah yang berlaku akan mendatangkan kerisauan kepada masyarakat setempat. Maka pendekatan baru perlulah diambil atau dilaksanakan bagi tujuan membendung permasalahan jenayah pecah rumah ini (Za'im et al., 2017).

\section{Senario Jenayah Pecah Rumah di Malaysia}

Di Malaysia, jenayah indeks ini telah diklasifikasikan sebagai jenayah harta benda dan jenayah kekerasan (Polis Diraja Malaysia, 2020). Jenayah pecah rumah merupakan salah satu daripada jenayah indeks di bawah kategori jenayah harta benda. Seterusnya, jenayah indeks harta benda ini juga merupakan jenayah utama yang menyumbangkan kepada kadar indeks jenayah di Malaysia (Polis Diraja Malaysia, 2020). Jenayah merupakan suatu kesalahan yang dilakukan oleh seseorang individu itu dengan niat hendak melakukan suatu kesalahan. Kesalahan yang dikatakan adalah merujuk kepada kesalahan yang salah di sisi undang-undang jenayah seperti mencuri, merompak, membunuh dan sebagainya (Mohd Zamre et al., 2017). Oleh yang demikian, trend jenayah indeks di Malaysia bagi tempoh 2015 sehingga 2020 boleh dilihat dengan jelas sebagaimana yang ditunjukkan pada Rajah 1 .

Rajah 1: Trend Jenayah Indeks keseluruhan di Malaysia bagi tempoh 2015 hingga 2020

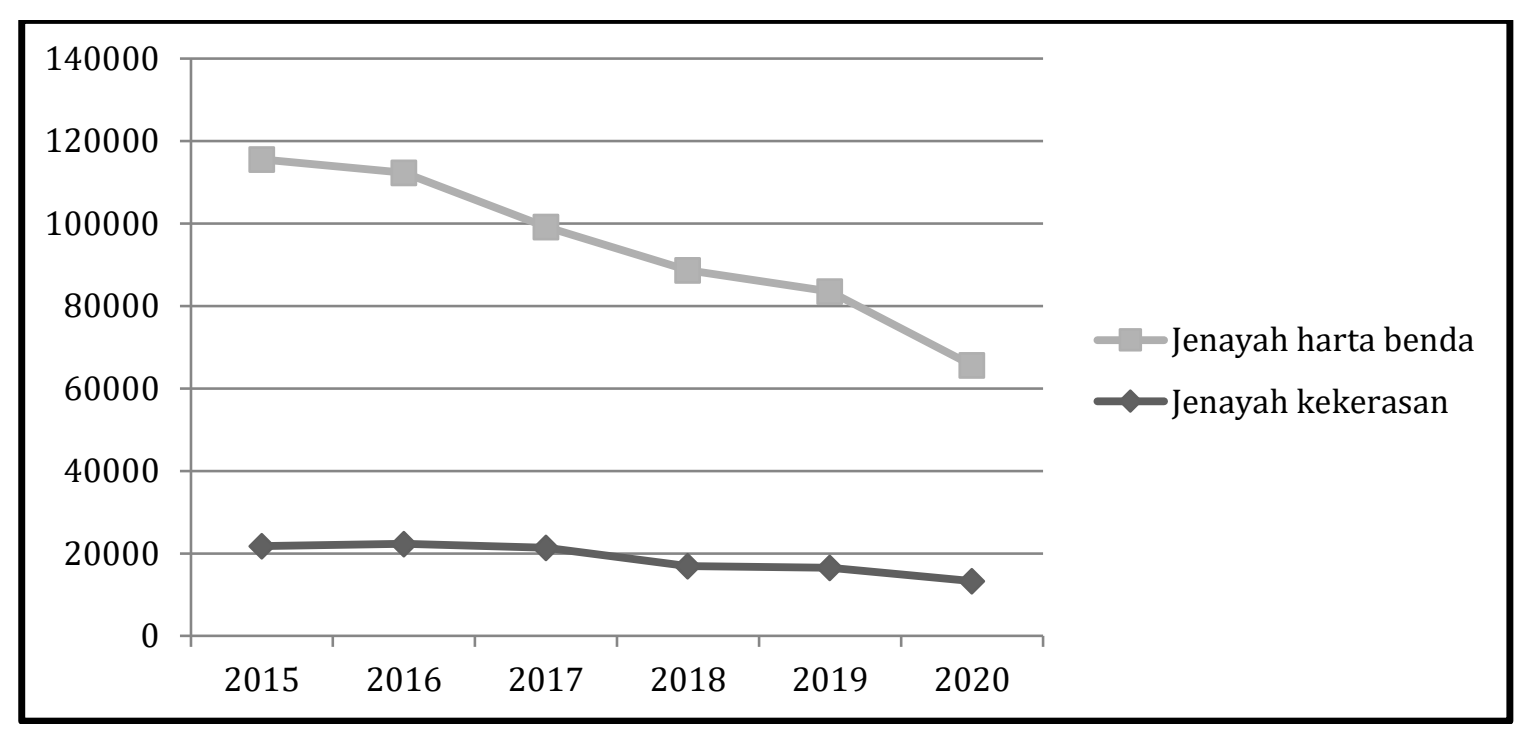

Sumber: PDRM (2020)

Berdasarkan Rajah 1, trend jenayah indeks keseluruhan di Malaysia bagi tempoh 2015 sehingga 2020, jenayah kekerasan telah mencatatkan jumlah sebanyak 112177 kes atau 19.86 peratus bagi tempoh lima tahun dari 2015 sehingga 2020. Manakala jenayah harta benda telah mencatatkan 452650 kes atau 80.1 peratus bagi tempoh yang sama. Melalui trend tersebut jelas menunjukkan bahawa jenayah harta benda mencatatkan jumlah kes yang lebih tinggi berbanding jenayah kekerasan bagi tempoh sepanjang 
DOI: https://doi.org/10.47405/mjssh.v6i9.1042

tahun 2015 hingga 2020. Maka dapat dilihat bahawa jenayah indeks harta benda merupakan penyumbang utama indeks jenayah di Malaysia bagi tempoh tersebut.

Jadual 1: Statistik Jenayah Indeks Keseluruhan Di Malaysia 2015-2020

\begin{tabular}{|c|c|c|c|c|c|c|}
\hline Tahun & 2015 & 2016 & 2017 & 2018 & 2019 & 2020 \\
\hline \multicolumn{7}{|l|}{ Jenayah Kekerasan : } \\
\hline Bunuh & 499 & 456 & 379 & 323 & 313 & 253 \\
\hline Rogol & 2047 & 1886 & 1835 & 1648 & 1738 & 1582 \\
\hline Samun Berkawan Bersenjata Api & 62 & 65 & 31 & 31 & 17 & 6 \\
\hline $\begin{array}{l}\text { Samun Berkawan Tanpa Bersenjata } \\
\text { Api }\end{array}$ & 10718 & 10907 & 9779 & 6543 & 6058 & 4323 \\
\hline Samun Bersenjata Api & 14 & 18 & 3 & 9 & 8 & 5 \\
\hline Samun Tanpa Bersenjata Api & 2954 & 3463 & 4315 & 3688 & 3646 & 2992 \\
\hline Mencederakan & 5516 & 5531 & 5024 & 4660 & 4714 & 4118 \\
\hline Jumlah & 21810 & 22326 & 21366 & 16902 & 16494 & 13279 \\
\hline $\begin{array}{l}\text { Jumlah Keseluruhan } \\
\text { Kekerasan : }\end{array}$ & 112177 & & & & & \\
\hline \multicolumn{7}{|l|}{ Jenayah Harta Benda : } \\
\hline Curi & 18078 & 19894 & 19204 & 19927 & 19608 & 16725 \\
\hline Curi Motokar & 12049 & 10607 & 8482 & 7413 & 6818 & 4599 \\
\hline Curi Motosikal & 38565 & 34754 & 31577 & 26779 & 22507 & 16059 \\
\hline Curi Van/Lori/Jentera Berat & 3395 & 3050 & 2099 & 1761 & 1550 & 921 \\
\hline Curi Ragut & 2362 & 2963 & 240 & 138 & 0 & 0 \\
\hline Pecah Rumah & 19286 & 18760 & 16200 & 15742 & 16498 & 14040 \\
\hline Jumlah & 93735 & 90028 & 77802 & 71760 & 66981 & 52344 \\
\hline $\begin{array}{l}\text { Jumlah Keseluruhan } \\
\text { Harta Benda : }\end{array}$ & 452650 & & & & & \\
\hline Jumlah Jenayah Indeks & 115545 & 112354 & 99168 & 88662 & 83475 & 65623 \\
\hline $\begin{array}{l}\text { Jumlah Jenayah } \\
\text { Indeks Keseluruhan : }\end{array}$ & 564827 & & & & & \\
\hline
\end{tabular}

Sumber: Polis Diraja Malaysia (2020)

Berdasarkan Jadual 1, statistik menunjukkan jenayah indeks keseluruhan di Malaysia dari tahun 2015 sehingga 2020 dan dapat dilihat jenis-jenis jenayah indeks yang diklasifikasikan sebagai jenayah harta benda dan jenayah kekerasan. Statistik turut memperlihatkan jenayah indeks kekerasan terdiri daripada jenayah bunuh, rogol, samun berkawan bersenjata api, samun berkawan tanpa bersenjata api, samun bersenjata api, samun tanpa bersenjata api dan mencederakan. Manakala bagi jenayah indeks harta benda terdiri daripada jenayah curi, curi motokar, curi motosikal, curi van/lori/jentera, curi ragut dan pecah rumah. Berdasarkan Jadual 1, jenayah harta benda yang mencatatkan jumlah kes keseluruhan iaitu lebih daripada 100000 kes iaitu jenayah curi motosikal yang mencatatkan jumlah sebanyak 170241 kes, jenayah curi yang mencatatkan jumlah sebanyak 113436 kes dan jenayah pecah rumah yang mencatatkan sebanyak 100526 kes bagi tempoh 2015 hingga 2020.

Berdasarkan Jadual 2, statistik menunjukkan jenayah pecah rumah mengikut negeri di Malaysia bagi tempoh dari tahun 2015 hingga 2020. Berdasarkan statistik tersebut, dapati bahawa negeri Selangor telah mencatatkan jumlah kes tertinggi dalam tempoh bagi tahun 2015 hingga 2020 iaitu sebanyak 25654 kes atau 25.5 peratus. Walau bagaimanapun, negeri Selangor mencatatkan penurunan kes dari tahun 2015 iaitu 5805 kes sehingga tahun 2018 kepada 3515 kes. Pada tahun 2020, negeri Selangor mencatatkan penurunan kes lagi kepada 3025 kes dari tahun 2019 iaitu 3679 kes. Statistik menunjukkan negeri Selangor mengalami trend penurunan dalam jenayah pecah rumah bagi tempoh tersebut. Seterusnya, negeri yang merekodkan jumlah jenayah pecah rumah terendah bagi tempoh tersebut adalah negeri Perlis iaitu sebanyak 594 kes atau 0.6 peratus. Negeri Perlis dilihat mencatatkan penurunan kes dari tahun 2015 iaitu 102 kes sehingga tahun 2018 kepada 54 kes. Tetapi mencatatkan 
DOI: https://doi.org/10.47405/mjssh.v6i9.1042

peningkatan kes pada tahun 2019 iaitu 111 kes sehingga tahun 2020 iaitu 155 kes yang mana peningkatan ini masih tidak begitu ketara berbanding negeri lain.

Jadual 2: Statistik Jenayah Pecah Rumah Mengikut Negeri Di Malaysia 2015-2020

\begin{tabular}{lllllll}
\hline Tahun & $\mathbf{2 0 1 5}$ & $\mathbf{2 0 1 6}$ & $\mathbf{2 0 1 7}$ & $\mathbf{2 0 1 8}$ & $\mathbf{2 0 1 9}$ & $\mathbf{2 0 2 0}$ \\
\hline Johor & 1440 & 1475 & 1211 & 1239 & 1364 & 1273 \\
Kedah & 1499 & 1287 & 1350 & 1130 & 1138 & 980 \\
Kelantan & 893 & 682 & 570 & 699 & 929 & 626 \\
Kuala Lumpur & 1907 & 1867 & 1188 & 1104 & 1088 & 949 \\
Melaka & 445 & 544 & 567 & 591 & 681 & 487 \\
Negeri Sembilan & 998 & 1023 & 895 & 873 & 765 & 660 \\
Pahang & 795 & 719 & 794 & 861 & 718 & 604 \\
Perak & 1134 & 915 & 859 & 1023 & 1064 & 666 \\
Perlis & 102 & 85 & 87 & 54 & 111 & 155 \\
Pulau Pinang & 1150 & 917 & 868 & 855 & 1036 & 736 \\
Sabah & 1544 & 1757 & 1908 & 1881 & 1806 & 1332 \\
Sarawak & 1273 & 1540 & 1314 & 1497 & 1623 & 1946 \\
Selangor & 5805 & 5497 & 4133 & 3515 & 3679 & 3025 \\
Terengganu & 301 & 452 & 456 & 420 & 496 & 601 \\
\hline Jumlah keseluruhan & 19286 & 18760 & 16200 & 15742 & 16498 & 14040 \\
\hline
\end{tabular}

Sumber: Polis Diraja Malaysia (2020)

Berdasarkan statistik berkenaan dapat disimpulkan bahawa jelas menunjukkan jenayah pecah rumah merupakan salah satu jenayah harta benda yang menjadi penyumbang kepada kadar jenayah indeks di Malaysia. Walaupun, indeks jenayah mengalami penurunan tetapi masyarakat masih merasakan kadar jenayah masih meningkat dan kekal sama, maka ini menyebabkan wujudnya perasaan ketakutan terhadap jenayah oleh masyarakat. Permasalahan jenayah pecah rumah yang berlaku akan menjejaskan kualiti hidup penduduk setempat di sesebuah kawasan dan ini akan mengganggu kesejahteraan hidup mereka (Marzilla et al., 2019). Kebanyakan kes jenayah, jenayah pecah rumah merupakan jenayah yang menjejaskan atau merosakkan keamanan hidup masyarakat. Ia juga dianggap suatu masalah utama dalam masyarakat (Farzad et al., 2014). Kejadian jenayah sering kali berlaku di kawasan persekitaran yang lebih terbuka dan kawasan orang awam. Ketiadaan perancangan yang khusus berkait ruang di kawasan kediaman akan mengakibatkan wujudnya suatu peluang jenayah berlaku dalam kawasan kejiranan (Marlyana et al., 2018).

Justeru itu, jenayah boleh menjejaskan tahap keselamatan, kestabilan dan keharmonian institusi sosial sesebuah negara (Mohd Zamre et al., 2017). Maka artikel ini bertujuan membincangkan faktor yang menyumbang kepada berlakunya jenayah indeks pecah rumah ini perlu dilihat supaya dapat menjadikan garis panduan dalam membendung jenayah ini di samping dapat meningkatkan kesedaran masyarakat mengenai jenayah pecah rumah ini. Masalah jenayah ini sememangnya akan memberikan kesan kepada kesejahteraan masyarakat juga turut akan diperlihatkan supaya dapat membuka mata pelbagai pihak berkuasa dan masyarakat mengenai isu jenayah ini jika tidak dibendung dengan baik.

\section{Langkah Pencegahan Jenayah Pecah Rumah}

Pencegahan jenayah adalah suatu isu yang sangat serius dan merupakan suatu konsep yang meliputi pelbagai aspek serta penglibatan masyarakat dalam usaha mengelakkan berlakunya masalah jenayah (Nurhafilah, 2015). Pencegahan jenayah telah menjadi suatu perkara penting dan sebagai ukuran utama dalam menjamin kehidupan masyarakat yang lebih selesa, selamat dan sempurna (Saravanan, 2010). Peningkatan masalah jenayah ini telah menggugat telah menggugat keselamatan masyarakat setempat di Malaysia. Pencegahan merupakan suatu langkah penting dalam membentuk pencegahan secara menyeluruh dan bersistematik terhadap harta benda yang dikawal serta menghalang daripada berlakunya sesuatu kejadian jenayah (Mohd Zul Fahmi, 2019). 
Berdasarkan Teori pencegahan jenayah iaitu Teori Defensible Space yang diperkenalkan oleh Newman (1972) menyatakan terdapat dua tingkah laku sosial iaitu dari segi kewilayahan dan pengawasan semula jadi. Aspek kewilayahan merujuk kepada perasaan kepunyaan atau sense of belonging yang ada pada setiap penduduk yang mendiami sesebuah kawasan itu. Berdasarkan konsep ini, apabila seseorang penduduk itu menganggap mereka pemilik kawasan tersebut maka secara tidak langsung perasaan tanggungjawab untuk memelihara kawasan tersebut akan wujud dalam diri mereka. Ia turut meliputi keseluruhan kawasan persekitaran mereka. Oleh yang demikian, sesebuah kawasan itu tidak akan mudah terancam dengan perlakuan jenayah atau sebarang bentuk ancaman lain sekiranya wujudnya perasaan kepunyaan serta semangat kejiranan dalam komuniti kawasan itu. Ini kerana dengan wujudnya hubungan yang baik antara komuniti di sesebuah kawasan itu maka mereka secara semula jadinya akan menjadi peka terhadap individu yang masuk ke dalam persekitaran kawasan komuniti mereka. Pengawasan semula jadi itu merujuk kepada penduduk dalam komuniti di sesebuah kawasan itu mampu mengenal pasti segala bentuk peluang jenayah yang boleh berlaku dalam komuniti mereka (Mohd Zul Fahmi, 2019; Ainur \& Jalaluddin, 2010).

Oleh itu, kajian ini cenderung untuk melihat beberapa konsep langkah-langkah pencegahan yang boleh digunakan bagi mencegah permasalahan jenayah pecah rumah berdasarkan beberapa kajian lepas khususnya dari segi pemantauan pihak berkuasa PDRM, pengawasan komuniti, meningkatkan ciri-ciri keselamatan dan pemilihan komuniti berpagar.

\section{Pemantauan Pihak Berkuasa PDRM}

Zaiton (2020) menyatakan bahawa di Malaysia tindakan pencegahan jenayah ini sememangnya telah dilaksanakan oleh pihak berkuasa Polis Diraja Malaysia (PDRM). Perkara ini telah termaktub di bawah fungsi pasukan polis sebagaimana yang dinyatakan dalam Akta Polis 1967 di bawah Seksyen 3(3). Berdasarkan Akta Polis 1967 iaitu di bawah Seksyen 3(3) yang mana menyatakan bahawa demi kedaulatan sesebuah negara dan kesejahteraan masyarakat, pasukan Polis Diraja Malaysia (PDRM) bertanggungjawab dalam memelihara undang-undang dan ketenteraman, mengekalkan keamanan dan keselamatan Malaysia, mencegah dan mengesan penjenayah, menangkap dan mendakwa pesalahpesalah serta mengumpul risikan keselamatan (Polis Diraja Malaysia, 2016a).

Sementara itu, menurut Ahmad Tarmizi et al. (2017) tindakan pembanterasan jenayah yang dilakukan oleh Polis Diraja Malaysia (PDRM) dapat menurunkan kadar jenayah yang berlaku melalui pelbagai inisiatif dan perlaksanaan program pencegahan. Kadar jenayah juga dapat dikawal dan dikurangkan jika adanya kerjasama antara Polis Diraja Malaysia (PDRM) dengan masyarakat di sesebuah kawasan itu. Ini di sokong oleh Faizah (2015) yang berpendapat keselamatan dan ketenteraman awam di sesebuah bandar bukan sahaja menjadi tanggungjawab pihak polis malah penglibatan bersama daripada masyarakat setempat juga amat diperlukan dalam bersama-sama menjaga kawasan persekitaran mereka. Hal ini kerana menurut Marzilla et al. (2019) sekiranya rondaan pihak Polis Diraja Malaysia (PDRM) yang dilaksanakan kurang kerap dan tidak menyeluruh boleh mendorong berlakunya perlakuan jenayah pecah rumah di sesebuah kawasan perumahan itu.

Kemudian, peranan pihak polis sangat penting dalam kriminologi kerana tugas utama mereka iaitu menangkap pesalah dan menyelesaikannya sehingga perbicaraan bagi mencegah jenayah. Walaupun pihak polis tidak dapat mengurangkan permasalahan jenayah yang berlaku dalam persekitaran masyarakat sepenuhnya tetapi permasalahan jenayah ini masih dapat dikawal pada tahap yang memuaskan (Sunjida, 2019). Menurut Saravanan (2010) segala bentuk maklumat jenayah yang mencurigakan yang disalurkan oleh masyarakat setempat kepada pihak polis membolehkan pihak berkuasa polis merancang bagi tujuan pencegahan jenayah yang berlaku di kawasan tersebut. Oleh yang demikian, adalah menjadi tanggungjawab pihak berkuasa dalam mengawal serta menangani segala bentuk ancaman jenayah yang berlaku dalam sesebuah komuniti itu (Nazirah et al., 2021).

Kesimpulannya, peranan pihak berkuasa Polis Diraja Malaysia (PDRM) sangat penting dalam usaha mengawal dan mencegah masalah jenayah khususnya jenayah pecah rumah yang berlaku dalam sesebuah komuniti. 


\section{Pengawasan Komuniti}

Istilah yang sepadan dan dicadangkan oleh Dewan Bahasa Dan Pustaka (DBP) bagi Community Policing adalah pengawasan komuniti atau pengawasan masyarakat. Pengawasan komuniti merupakan sebahagian daripada strategi utama bagi menjaga serta mengawal keselamatan hidup masyarakat di Malaysia. Pengawasan komuniti sememangnya telah lama wujud dalam kehidupan masyarakat kini seperti pengawasan dari kejiranan, Rakan COP, Skim Rondaan Sukarela (SRS) dan Sistem Patrol. Pengawasan komuniti ini memberi penekanan kepada masyarakat bagi mengambil sebarang bentuk tindakan dalam tujuan pencegahan jenayah secara bersepadu dalam mencegah masalah jenayah yang berlaku dalam kawasan kejiranan mereka (Zaiton, 2020). Menurut Budi Anto et al. (2020) hasil kajian dapati penglibatan Rukun Tetangga menerusi Skim Rondaan Sukarela (SRS) telah membawa kepada pengertian rasa selamat dalam kalangan komuniti bagi mencegah segala bentuk aktiviti jenayah serta menangani isi keselamatan awam. Hal ini kerana menurut Marzilla et al. (2019) ketiadaan aktiviti rondaan atau pengawasan yang dilakukan oleh pihak Rukun Tetangga, Rela mahupun pengawal keselamatan di sesebuah kawasan perumahan yang bertindak sebagai menjaga keselamatan kawasan kediaman akan menyebabkan berlakunya perlakuan jenayah pecah rumah di kawasan tersebut.

Sementara itu, menurut Marzilla et al. (2019) kadar jenayah pecah rumah di sesebuah kawasan komuniti dapat dikurangkan atau dicegah dengan adanya kerjasama yang baik daripada penduduk setempat, pihak swasta dan NGO yang berkaitan. Ini di sokong oleh Nur Hidayah et al., (2020) menyatakan bahawa penglibatan penduduk menerusi Rukun Tetangga dapat menjaga keselamatan dan kualiti hidup serta mencegah jenayah yang berlaku dalam kawasan persekitaran perumahan mereka. Menurut Ahmad Zaharuddin dan Nur Syafiqah (2016) aktiviti Rukun Tetangga bukan sahaja dapat membantu mencegah jenayah yang berlaku dalam kawasan komuniti malah dilihat sebagai suatu petunjuk kepada tahap kesejahteraan masyarakat. Ini kerana dengan kerjasama yang dilakukan seperti aktiviti rondaan, gotong-royong secara bersama komuniti setempat dapat mengeratkan hubungan silaturahim dan kejiranan antara satu sama lain. Menurut Norwahidah dan Novel (2016) aktiviti pencegahan jenayah yang diperluaskan bukan sahaja hanya penglibatan daripada pihak penguatkuasaan sahaja malah kerjasama daripada komuniti setempat melalui program pembangunan komuniti.

Kemudian, Mohd Syariefudin et al. (2020) menyatakan bahawa di Malaysia penubuhan kumpulan WhatsApp dalam kalangan komuniti di sebuah taman perumahan yang dijadikan sebagai penghubung antara masyarakat dalam Rukun Tetangga telah berjaya membantu pihak polis dalam menangani masalah jenayah pecah rumah di kawasan kejiranan. Aktiviti Rukun Tetangga juga merupakan suatu usaha di peringkat akar umbi bagi mencegah masalah jenayah daripada terus berlaku di sesebuah kawasan kejiranan. Menurut Norcikeyonn et al. (2021) kewujudan Skim Rondaan Sukarela (SRS) yang terdiri daripada penglibatan masyarakat setempat telah berjaya mencegah pelbagai kes jenayah seperti jenayah pecah rumah, ragut dan kenderaan di kawasan perumahan. Zaiton (2016) mendapati 5 hingga 10 peratus kes jenayah telah dapat dikurangkan melalui strategi Program Pengawasan Komuniti. Tambahan pula, dengan adanya usaha khusus daripada komuniti penduduk bagi mencegah jenayah seperti jenayah pecah rumah dan jalanan ini dapat memperkayakan modal sosial dan seterusnya membawa kepada keselamatan masyarakat secara subjektif dan objektif (Anna \& Shigeo, 2018).

Kesimpulannya, pengawasan komuniti dengan adanya kerjasama antara masyarakat setempat dalam usaha mencegah jenayah amatlah digalakkan bagi membantu pihak PDRM dalam mengawal masalah jenayah khususnya jenayah pecah rumah di sesebuah kawasan perumahan mahupun bandar. Menurut, Zaiton (2020) kewujudan pengawasan komuniti ini dapat menjadi sebahagian daripada strategi terancang dalam usaha menjaga dan mengawal keselamatan hidup masyarakat di Malaysia.

\section{Meningkatkan Ciri-Ciri Keselamatan}

Menurut Mohd Zul Fahmi (2019) kediaman yang mempunyai pencegahan jenayah secara fizikal seperti mempunyai ciri keselamatan dari segi pencahayaan lampu, pemasangan kunci dan pagar, alat penggera keselamatan, kamera litar tertutup (CCTV) dan sebagainya dapat mengurangkan jenayah 
kecurian dan rompakan. Ini di sokong oleh Faizah (2015) yang menyatakan bahawa pemasangan kamera litar tertutup (CCTV) di tempat awam, premis, kediaman atau sebagainya dapat membantu dalam mencegah jenayah sekali gus mengurangkan indeks jenayah. Menurut Marzilla et al. (2019) ciri-ciri keselamatan dari segi pemasangan CCTV (closed-circuit television), gril tingkap, rumah berpagar, pemasangan alat penggera keselamatan dan sebagainya sangat diperlukan bagi sesebuah kediaman. Oleh itu, ciri-ciri keselamatan tambahan dapat meningkatkan tahap keselamatan sesebuah kediaman daripada dicerobohi atau dimasuki oleh penjenayah. Ketiadaan ciri keselamatan tambahan sebegini cenderung mendorong suatu perlakuan jenayah pecah rumah berlaku dengan mudah.

Seterusnya, Faizah et al. (2015) menjelaskan penyediaan kelengkapan keselamatan amat penting di dalam sesebuah bandar atau kawasan perumahan. Ketiadaan elemen keselamatan seperti pemasangan CCTV dan sebagainya akan memberikan peluang perlakuan jenayah berlaku di kawasan tersebut. Fauziah (2016) bersetuju dan menyatakan bahawa sebagai usaha dalam mengekang serta mengurangkan masalah jenayah pemasangan kamera litar tertutup (CCTV) amatlah diperlukan untuk digunakan bagi mendapatkan imej penjenayah yang melakukan perlakuan jenayah di sesuatu kawasan itu. Norwahida et al. (2016) mendapati bahawa projek inovasi dengan pemasangan Unity Alarm telah berjaya mengurangkan masalah jenayah di kawasan kejiranan. Pemasangan penggera dan bunyi siren yang menyerupai siren polis telah menyebabkan penjenayah sukar melakukan aktiviti jenayah mereka dan berasa risiko ketika melakukan aktiviti jenayah. Pemasangan penggera ini telah berjaya menurunkan kejadian kes seperti pecah rumah, kecurian motosikal, samun dan ragut di kawasan kejiranan.

Perkara serupa turut dinyatakan oleh Nor-Ina et al. (2019) dimana pemasangan alat penggera keselamatan sangat penting bagi membantu seseorang yang berada dalam keadaan bahaya atau kecemasan akibat daripada sebarang ancaman jenayah khususnya jenayah pecah rumah. Hal ini kerana alat penggera ini dapat mengundang perhatian umum masyarakat yang ada di kawasan kejiranan bagi menandakan terdapatnya suatu kejadian yang tidak diingini berlaku. Seterusnya, menurut Mohd Zul Fahmi (2019) pula pencahayaan lampu di kawasan luar kediaman juga penting bagi mencegah jenayah berlaku di kawasan perumahan. Ini kerana apabila kawasan luar kediaman kurang diterangi oleh pencahayaan lampu maka penjenayah menjadi tidak begitu berisiko untuk melakukan aktiviti jenayahnya dan kebarangkalian untuk berlakunya jenayah khususnya jenayah pecah rumah agak tinggi di kediaman tersebut. Faizah et al. (2015) bersetuju bahawa pencahayaan yang kurang di sesebuah kawasan itu akan menggalakkan berlakunya perlakuan jenayah di kawasan tersebut khususnya pada malam hari.

Kesimpulannya, pencegahan jenayah dapat dilaksanakan sekiranya adanya ciri-ciri keselamatan yang baik di sesebuah kediaman atau kejiranan itu. Maka dengan itu, masyarakat harus peka dalam meningkatkan ciri-ciri keselamatan di kediaman dan kejiranan masing-masing bagi mengelakkan daripada menjadi mangsa jenayah pecah rumah.

\section{Pemilihan Komuniti Berpagar}

Masyarakat Malaysia kini lebih cenderung membuat pemilihan kepada perumahan komuniti berpagar serta berpengawal akibat daripada masalah jenayah pecah rumah, rompakan serta kecurian yang kian meningkat saban hari. Kajian juga dapati bahawa pemilihan masyarakat terhadap perumahan komuniti berpagar dan berpengawal ini kerana bagi mendapatkan keselamatan yang baik, rukun tetangga dan keadaan sosial kawasan perumahan yang memberikan keselesaan kepada mereka. Tambahan pula, perumahan sebegini dilengkapi dengan pos keselamatan kawasan di setiap pintu masuk utamanya dan turut dilengkapi dengan CCTV yang mampu merakam setiap perilaku jenayah yang berlaku di kawasan perumahan tersebut (Nur Hidayah et al., 2020). Ini di sokong oleh Norwahidah dan Novel (2016) menyatakan bahawa suatu persekitaran yang kondusif bukan sahaja dapat memberikan keselesaan serta menjamin keselamatan malah memberikan kualiti kehidupan kepada masyarakat di sesebuah kawasan itu.

Menurut Norcikeyonn et al. (2021) kawasan yang mempunyai kadar jenayah yang tinggi digalakkan untuk membangunkan kawasan jenis komuniti berpagar bagi mencegah permasalahan jenayah. Namun 
begitu menurut Zurinah dan Jalaluddin (2018) kawasan perumahan komuniti berpagar ini tidak begitu digalakkan dibangunkan di kawasan yang berhampiran dengan kawasan perkampungan kerana akan memberikan kesan negatif. Hal ini kerana pemilihan lokasi pembangunan perumahan komuniti berpagar yang tidak terancang akan membawa kesan negatif kepada perancangan serta pembangunan bandar di sesebuah kawasan itu. Sementara itu, menurut Siti Fatimah dan Wan Nadzri (2017) pembangunan perumahan komuniti berpagar ini telah banyak didirikan di kawasan-kawasan bandar besar seperti Kuala Lumpur, Pulau Pinang, Johor Bharu dan Ipoh. Perkembangan komuniti berpagar ini berterusan di kawasan bandar akibat daripada peningkatan kes jenayah yang berlaku. Tambahan pula, disebabkan aspek keselamatan menjadi keutamaan maka kebanyakan penduduk di Malaysia banyak memilih perumahan komuniti berpagar bagi menjamin keselamatan mereka.

Tan Pei dan Mat Tawi (2021) mendapati bahawa perumahan komuniti berpagar dan berpengawal ini merupakan sebuah kawasan komuniti yang berpagar serta dilengkapi dengan akses keluar masuk yang dikawal dengan menggunakan sistem keselamatan yang baik. Oleh yang demikian, dengan dilengkapi pelbagai elemen keselamatan seperti dinding, pagar, pondok pengawal dan sebagainya mampu memberikan rasa selamat dan aman kepada komuniti dalam kawasan perumahan tersebut. Alauddin dan Ooi Seong (2016) turut menyatakan perumahan komuniti berpagar dan berpengawal mempunyai ciri-ciri keselamatan seperti kawalan di pintu masuknya, pengawal keselamatan yang berbayar untuk melakukan rondaan, sistem pemantauan yang berpusat serta close circuit television (CCTV). Oleh itu, dengan kawalan yang ketat dan aspek keselamatan yang rapi sebegini dapat mencegah daripada pencerobohan penjenayah berlaku di kawasan tersebut.

Kesimpulannya, perumahan komuniti berpagar dapat membantu pencegahan jenayah khususnya jenayah pecah rumah berlaku dalam kawasan sesebuah komuniti. Permasalahan jenayah yang sering berlaku di kawasan kejiranan telah mewujudkan perasaan tidak selamat dan takut akan jenayah serta menimbulkan perasaan gusar akan aspek keselamatan dalam diri masyarakat. Oleh yang demikian, dengan mendiami kawasan perumahan komuniti berpagar dan berpengawal dapat mengurangkan rasa terancam penduduk akan aspek keselamatan dan mencegah daripada berlakunya kejadian jenayah pecah rumah, ragut, dan sebagainya (Alauddin \& Ooi Seong, 2016).

\section{Kesimpulan}

Kesimpulannya, permasalahan jenayah pecah rumah ini merupakan suatu masalah sosial yang dapat mengancam keselamatan serta kesejahteraan masyarakat. Oleh itu, kerjasama antara masyarakat di sesebuah kawasan itu amatlah diperlukan bagi membantu pihak berkuasa dalam mencegah perlakuan jenayah pecah ini daripada terus berlaku. Maka dengan pelbagai langkah pencegahan yang dibincangkan dalam kajian ini ia mampu membantu pihak berkuasa dan masyarakat dalam mengaplikasikannya bagi usaha mencegah segala bentuk perlakuan jenayah pecah rumah ini.

\section{Rujukan}

Abd Rahman, A. T., Kanyo, N.-I., Mohd Nor, N., Salleh, N., Jubit, N., Lajimin, S. A.-N. A., \& Samuni, N. (2017). Pelakuan Jenayah Harta Benda Di Kawasan Hotspot Di Sabah: Satu Penemuan. Jurnal Komunikasi Borneo Edisi Khas (Konvokesyen Ke-19 UMS), 104-119.

Abdul Manap, N. H., Tahir, Z., \& Abd Malek, J. (2020). Faktor Pemilihan Perumahan Komuniti Berpagar Dan Kepentingan Rukun Tetangga Dalam Pencegahan Jenayah. Journal of Social Sciences and Humanities, 17(8), 234-245.

Abdullah, M. S., Marzuki, M., Abdul Rahim, M. M., Kamarul Zaman, M. A., \& Kaspin, K. G. (2020). Penubuhan Rukun Tetangga (RT) Di Malaysia Daripada Perspektif Islam. Tinta Artikulasi Membina Ummah, 6(1), 99-111.

Ahmad Sabri, A. Z. S., \& Mohd Rashidi, N. S. H. (2016). Penerimaan Masyarakat Terhadap Rukun Tetangga Mengikut Jantina. Al-Hikmah, 8(2), 110-127.

Ahmad, Z., Md Darit, S., Sabar, R., \& Anuar, N. K. (2017). Mencegah jenayah dalam aspek titik spektrum jenayah. Conference on Corrections \& Criminal Justice 2017, 1-14. 
ANNA MALAI, S. (2010). Tahap Keberkesanan Langkah Pencegahan Jenayah Melalui Program Bandar Selamat Kajian Kes : Pusat Bandar Kajang (Issue Januari).

Azman, Z. (2016). Pendekatan ruang boleh dipertahankan dalam program komuniti untuk kanakkanak tidak terkawal di projek perumahan awam Desa Rejang, Setapak, Kuala Lumpur. Universiti Malaya Kuala Lumpur.

Azman, Z. (2020). Pengawasan Komuniti Dan Pencegahan Jenayah Di Malaysia: Sejarah Perkembangannya. The Malaysian Journal of Social Administration, 14(2), 39-61. https://ejournal.um.edu.my/index.php/MJSA/article/view/26993

Che Leh, F. (2016). Pelancongan bandar dan isu keselamatan: Kajian kes pelancong antarabangsa Kuala Lumpur. Geografia : Malaysian Journal of Society and Space, 12(8), 110-122.

Hassan, N., Mohd Razali, S., \& Mohamad, M. S. (2021). Cabaran Polis dan Tentera Mendepani Pandemik COVID-19. Journal of Social Sciences and Humanities, 18(3), 241-252.

Islam, S. (2019). Role of Police in the Criminal Justice System of Bangladesh: Need for Reformation. International Journal of Management, Technology, and Social Sciences, 4(1), 46-51. https://doi.org/10.47992/ijmts.2581.6012.0059

Jalilian, F., Mirzaei Alavijeh, M., Changizi, M., Ahmadpanah, M., Reza Amoei, M., \& Mostafavi, F. (2014). Factors Related to Burglary From the Perspective of Burglars: A Qualitative Study. Avicenna Journal of Neuro Psych Physiology, 1(2), 1-7. https://doi.org/10.17795/ajnpp-24260

Jubit, N., Masron, T., \& Marzuki, A. (2020). Spatial pattern of residential burglary. The case study: Kuching, Sarawak. Journal of the Malaysian Institute of Planners, 18(3), 190-201. https://doi.org/10.21837/PM.V18I13.785

Jubit, N., Masron, T., Nordin, M. N., \& Chabo, D. (2019). Aplikasi GIS dalam mengenal pasti kawasan hot spot jenayah harta benda di Kuching, Sarawak. Malaysian Journal of Society and Space, 15(4), 30-49. https://doi.org/10.17576/geo-2019-1504-03

Kamarulzaman, F. (2020). The effects of crime on Malaysia. https://www.emirresearch.com/theeffects-of-crime-on-malaysians/

Kanyo, N., Md Nor, N., Rainis, R., Abdul Rahman, A. T., \& Jubit, N. (2015). Jenayah dan agenda pembangunan di Malaysia: Satu tinjauan. Geografia - Malaysian Journal of Society and Space, 11(1), 124-134.

Kanyo, N., Rainis, R., Abdul Rahman, A. T., Mohd. Nor, N., Samuni, N., \& Lajimin, A.-N. A. (2019). Kesesuaian Pelaksanaan Langkah-Langkah Dalam Program Bandar Selamat Mengikut Perspektif Keruangan Di Sabah: Tinjauan Lokal. Journal of Social Sciences and Humanities, 16(8), 1-15.

Kementerian Dalam Negeri. (2021). Program Transformasi Kerajaan (GTP). Portal Rasmi Kementerian Dalam Negeri,.

M, M., CR, R. A., \& S, Z. (2019). Dilema masalah jenayah pecah rumah impak pembangunan Lebuhraya Baru Pantai (NPE). Malaysian Journal of Society and Space, 15(4), 80-91. https://doi.org/https://doi.org/10.17576/geo-2019-1504-06

Majid, R., \& Samat, N. (2017). Pemetaan Hot Spot Gis Dalam Kejadian Jenayah Kecurian Motosikal Di Bandaraya Alor Setar, Kedah Darul Aman. Buletin GIS \& Geomatik, 1, 9-19.

Marzukhi, M. A., Afiq, M. A., Leh, O. L. H., \& Abdullah, Y. A. (2018). the Defensible Space Concept in Neighbourhood Park. Journal of the Malaysian Institute of Planners, 16(3), 274-284. https://www.planningmalaysia.org/index.php/pmj/article/view/517/421

Matsukawa, A., \& Tatsuki, S. (2018). Crime prevention through community empowerment: An empirical study of social capital in Kyoto, Japan. International Journal of Law, Crime and Justice, 54(March), 89-101. https://doi.org/10.1016/j.ijlcj.2018.03.007

Md Latif, F. (2015). Ke arah pengurangan indeks jenayah jalanan di Pusat Bandar Kuala Lumpur. GEOGRAFIA OnlineTM Malaysian Journal of Society and Space, 11(4), 97-107.

Md Latif, F., Nordin, N. A., \& Au Yong, C. P. (2015). Rekabentuk bagi keselamatan bandar di Kuala Lumpur : Satu ulasan kritis. Malaysian Journal of Society and Space, 11(9), 40-53.

Md Latif, F., Nordin, N. A., \& Au-yong, C. P. (2015). Rekabentuk bagi keselamatan bandar di Kuala Lumpur: Satu ulasan kritis. Geografia-Malaysian Journal of Society and Space, 11(9), 40-53.

Mohd Nasaruddin, S. F., \& Osman, W. N. (2017). Perkembangan perumahan komuniti berpagar dan berpengawal dalam trend peningkatan kualiti hidup. Journal of Advanced Research in Business and Management Studies, 7(1), 60-66.

Mohd Tamring, B. A., Esa, M. S., \& Ibrahim, M. A. (2020). Hubungan Kaum dalam Kawasan Rukun 
Tetangga (KRT) di Pantai Barat Sabah. Malaysian Journal of Social Sciences and Humanities (MJSSH), 5(11), 147-158. https://doi.org/https://doi.org/10.47405/mjssh.v5i11.542

Mohd Zahir, M. Z., Tengku Zainudin, T. N. A., Rajamanickam, R., Mohd Shariff, A. A., Abd Rahman, Z., \& Hatta, M. (2017). Pendidikan Undang-Undang Sebagai Mekanisme Pencegahan Jenayah Dalam Kalangan Pelajar Sekolah Menengah Di Malaysia. In R. Ara Begum, F. Jalil, R. Md Khalid, M. A. Zahid, S. Harun, H. Janor, \& R. Markom (Eds.), Proceedings of The Tuanku Ja'afar Conference (TJC) 2017 Governance Towards Sustainable Development Goals (Issue November, pp. 379-391). Faculty of Law Universiti Kebangsaan Malaysia,.

Musa, N. (2015). Ilman Dan Kesannya Terhadap Pencegahan Jenayah. Jurnal Keputeraan Jilid 5 Tahun 1437H / 2016M, 5(November 2015), 1-18.

Polis Diraja Malaysia. (2016a). Dasar Utama Polis Diraja Malaysia. Urus Setia KPN (Komunikasi Korporat) Dengan Kerjasama Bahagian Telekomunikasi Dan Sistem Maklumat Ibu Pejabat Polis Diraja Malaysia,.

Polis Diraja Malaysia. (2016b). Jabatan Pencegahan Jenayah dan Keselamatan Komuniti (JPJKK). Urus Setia KPN (Komunikasi Korporat) Dengan Kerjasama Bahagian Telekomunikasi Dan Sistem Maklumat Ibu Pejabat Polis Diraja Malaysia,.

Polis Diraja Malaysia. (2020). Statistik Jenayah Indeks di Malaysia bagi tahun 2015 sehingga 2020.

Samuni, N., Kanyo, N., \& Mapjabil, J. (2021). Kesesuaian Langkah Memperkasakan Domain Bandar Berdaya Huni di Zon Black Spot Jenayah di Sabah. Malaysian Journal of Social Sciences and Humanities (MJSSH), 6(8), 150-161. https://doi.org/https://doi.org/10.47405/mjssh.v6i8.960

Sidal, A., \& Kang, O. S. (2016). Kesejahteraan Sosial Dalam Kehidupan Bandar: Perspektif Penghuni Kejiranan Berpengawal. Sarjana, 31(1), 55-69.

Tahir, Z., \& Abdul Malek, J. (2018). Kesesuaian lokasi pembangunan perumahan komuniti berpagar di Johor Bharu. Malaysian Journal of Society and Space, 14(2), 125-135. https://doi.org/10.17576/geo-2018-1402-10

Wen, T. P., \& Yaacob, M. T. (2021). Kesan Pembangunan Komuniti Berpagar dan Berpengawal (GACOS ) dari Aspek Sosial: Perspektif Penghuni dan Bukan Penghuni. Research in Management of Technology and Business, 2(1), 1305-1318.

Zahari, M. Z. F. (2019). Kriteria Utama Pencegahan Jenayah Menurut Perspektif Golongan Profesional Alam Bina Di Malaysia [Universiti Sains Malaysia]. https://ethesis.usm.my/jspui/handle/123456789/11367

Zainal Abidin, N., Lyndon, N., \& Abdul Rahim, M. H. (2016). Impak projek inovasi pencegahan jenayah kawasan perumahan: analisa daripada pandangan komuniti lokal. E-Bangi : Journal of Social Sciences and Humanities, 11(2), 427-449. https://ejournal.ukm.my/ebangi/article/viewFile/16076/5007

Zainudin, A. Z., \& Abdul Malek, J. (2010). Keberkesanan Program Bandar Selamat Dari Persepsi Penduduk Kajian Kes: Bandaraya Shah Alam. Jurnal Teknologi, 53, 13-34.

Zinalibdin, N., \& Lydon, N. (2016). Makna rasa selamat komuniti Malaysia dalam Program Skim Rondaan Sukarela: Kajian kes KRT Taman Putera Jaya, Kota Kinabalu, Sabah. Malaysian Journal of Society and Space, 12(5), 22-32. 